"The contributory pension scheme and the financial system development in Nigeria"

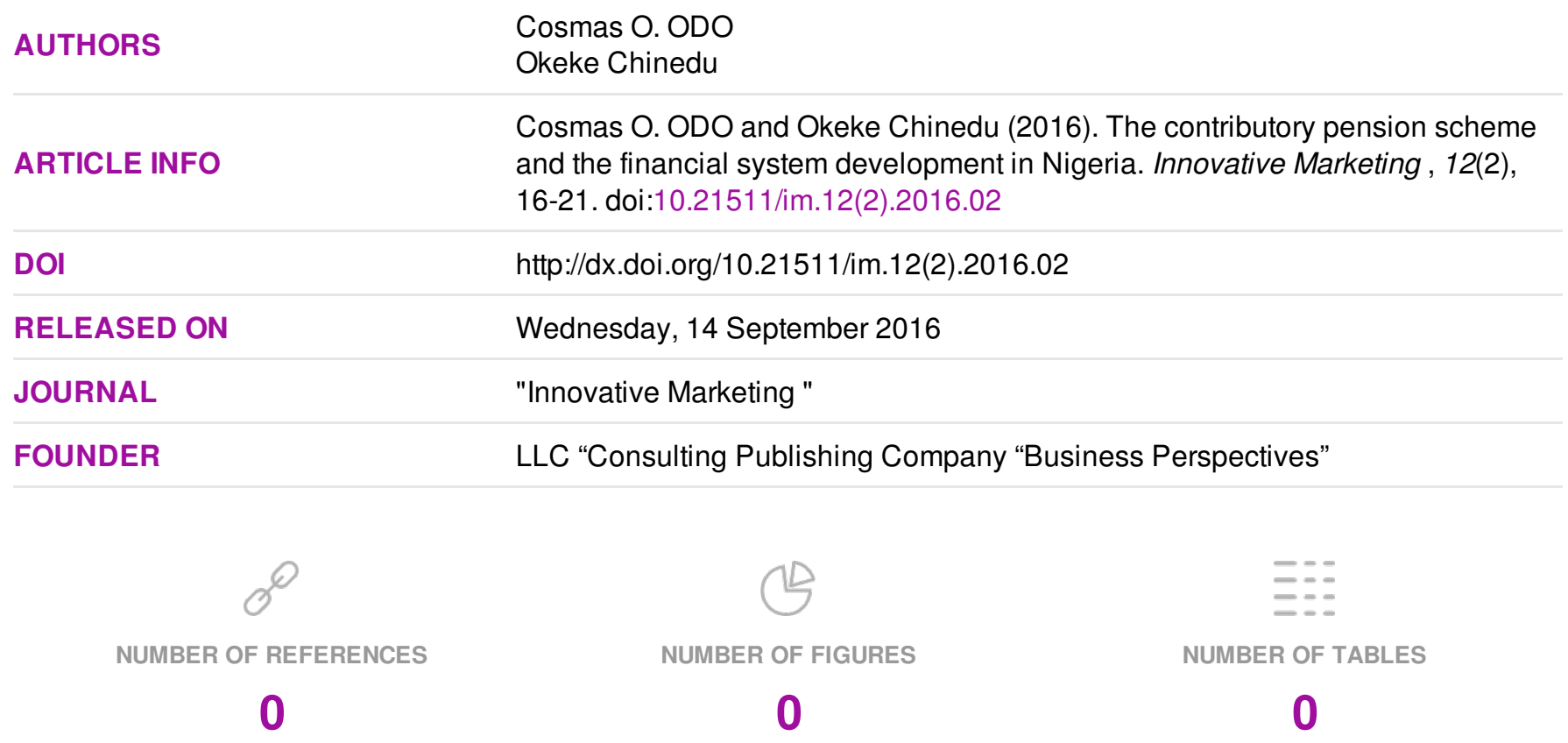

(C) The author(s) 2022. This publication is an open access article. 
Cosmas O. Odo (Nigeria), Okeke Chinedu (Nigeria)

\title{
The contributory pension scheme and the financial system development in Nigeria
}

\begin{abstract}
The article examined the influence of the contributory pension scheme on the financial system development in Nigeria. Evidence accumulated from both theoretical and empirical literature point to the power of contributory pension to deepen the financial system. An empirical work earlier done showed that the total domestic savings (TDS) increased during the post-pension period; and that the capital market capitalization rose significantly over the period. It was also observed that its implementation has created an impressive scenario whereby now pension funds account for $30 \%$ and $8 \%$ bond and stock markets capitalization, respectively. This is beside the increased activities in the life subsector of the insurance industry.
\end{abstract}

Keywords: pension, financial system development, contributory pension, pay-as-you-go.

JEL Classification: G230.

\section{Introduction}

Systems providing retirement benefits, for some years now, have come under severe pressure of a global proportion (Lindsay, 2009; Ellison, 2011). Factors linked to the crisis include the escalating costs of government expenditure in other sectors, the growing proportion of old people in the global population, increasing life expectancy and the impact of the recent global financial crisis (Alles, 2010). The Nigerian dimension highlights issues that border on sheer crass corruption, inadequate budgetary allocations to settle pension debts, among others, as the bane of the old pension system (Uwujaren, 2004; Oloja, 2010; Onwuamaeze, 2011). To arrest the rot, government passed the Pension Reforms Act, 2004 which replaced the old scheme with the contributory pension system. The reform agenda has clear and well articulated objectives which include, stemming the growth of pension liabilities, prompt payment of benefits, and inculcation of thrift among Nigerians towards old age and the development of simple, transparent and sustainable pension system (Anaesoronye, 2010; Onwuamaeze, 2011). As can be read into the reform agenda, a veiled target of the scheme is the development of the financial sector of Nigerian economy. The new pension system has been in force for ten years post inauguration. It may be of immense academic interest to establish to what extent the reform has been able to stimulate both private and national savings. This, as expected, could help to spur financial system development. The rest of the paper is discussed as follows.

(c) Cosmas O. Odo, Okeke Chinedu, 2016.

Cosmas O. Odo, Ph.D., Enugu State University of Science \& Technology, Enugu, Nigeria.

Okeke Chinedu, Branch Manager, Zenith Bank, PLC, Central Business District, Abuja, Nigeria.

\section{The pay-as-you-go pension system in Nigeria}

Nigeria, a former British Colony, received her pension tradition from Britain (Oluoma, 1986). This began when the Colonial Government in Nigeria (in circular No $19 / 1945$ of March, 24 ${ }^{\text {th }} 1945$ ) announced a superannuating pension for African staff employed by Government (Public Notice No 4, 1945). The relevant legal instrument that midwifed it was the Pension Ordinance of 1951 (Ogunshola, 1984, as quoted in Oluoma, 1986). The key feature of this pension scheme was its reliance on the payas-you-go financing method. This is a funding method that depends on inter-generational solidarity (Diamond, 1995). That is, a scheme where current workers pay (via pay roll taxes) for the pension benefits of those who have retired in the mutual hope that future workers will pay for theirs when they retire. The system works well in young economies and in societies where the dependency ratio is low (World Bank, 1994). The system, however, malfunctions when the pyramid is inverted. That is, when the proportion of old people to working population is relatively high. It, thus, becomes unsustainable. And this is what has happened to most global pension schemes, including those of Nigeria; and, hence, the current wave of demand for reform world-wide (World Bank, 1994).

The Nigerian scheme, prior to reform, was a variant of the pure conventional pay-as-you-go system. Funding was through annual budget allocations in which workers bore no direct financial burden, in form pay roll taxes, towards settlement of pensions (Ahmed, 2006; Balogun, 2006). The weakness of this funding strategy, in time, became apparent even as budget releases, which seldom came on schedule, were far short of due benefits (Balogun, 2006). According to him, pension arrears climbed to $\mathrm{N} 2$ trillion by the time the new pension law came into force. There were other problems that plagued the old pension system such as offer of unrealistic pension promises by 
politicians and diversion of pension funds by them, failure of state governments to provide pension own counterpart funds, inaccurate record of actual number of pensioners in the system, unimpressive disbursement system that allowed decrepit pensioners queue for long hours and under inclement weather to receive their stipends and outright embezzlement of pension funds (Odo and Igbeka, 2011). These avoidable flaws in the old pension system compelled its eventual reform which brought the contributory system into being in 2004 .

\section{Contributing pension system in Nigeria: features and safeguards}

Aware that the old pension system has proved unsustainable government passed the pension reform act of 2004 which made pension provision in the public and private sectors contributory. There are certain features that imbue the scheme with bright prospects of success.

2.1. Features. Individual Retirement Savings Account. The law allows every employee to open and maintain a savings account in his name with any pension fund administrator of his choice. The account is portable.

(a) Pension Fund Administrators (PFAs). Licensed PFAs are to open retirement savings account for employee, invest and manage the funds in fixed income securities and other instruments as may be determined by the Regulatory Agency, the National Pension Commission (NPC).

(b) Pension Assets Custodians (PACs). As created by the law, these licensed entities warehouse pension fund assets. Whereas the PFAs carry out investment functions, the PACs keep custody of funds assets. The arrangement provides checks and balances in the pension administration process.

(c) The National Pension Commission (NPC). This is the regulatory body that oversees the scheme.

(d) Retirement Benefits Bond Redemption Fund.

The law provides for a retirement benefits bond redemption fund to be maintained by the Central Bank of Nigeria $(\mathrm{CBN})$. The fund takes care of the transition financing gap created by the switch from pay-as-yougo to a funded system. The Federal Government is to credit it with an amount equal to $5 \%$ of the total monthly wage bill of federal workers. The fund is to settle the implicit pension debt in the old scheme.

2.2. Scheme safeguards. Separation of PFA and PAC. Their roles do not overlap. The PFA does not have custody of contributions of employees, nor does the custodian invest, but to the order of the PFA.

(a) Pension Asset Custodian Guarantee. In view of the large assets, it is expected to handle the custodian is required to issue a guarantee to the full sum of the assets it holds.

(b) Government Pension Contributions. Government's contribution is made a first charge on the consolidated Revenue Fund of the Federation.

\section{Pension reform and financial system development: an overview}

The exact nature of the impact of pension reform on the financial system development is contextdependent; that is, it depends on whether the financial system is developed or underdeveloped. Available data show that the introduction of private pension funds facilitates the development of the financial sector, particularly those economies that have underdeveloped financial sector and regulatory infrastructure (Quisser, 1999). It is also true that the availability of sufficient financial instruments has a positive impact on the pension reform process (Quisser, 1999).

Furthermore, it is a trite knowledge that a shift from the state pay-as-you-go system to a funded pension system creates huge capital accumulation (Diamond, 1995). The funds that accumulate over the intervening years prior to retirement must be invested in, say, securities that earn adequate returns capable of matching maturing pension liabilities. Hence, to speed up the reform process, there must be available sufficient array of financial securities that will absorb the accumulated funds. A deep capital market provides diverse investment instruments such as, insurance products, shares and bonds, both government and commercial. Most developing economies have very shallow capital markets (Quisser, 1999). It is on account of this that other macroeconomic policies like privatization of government enterprises get incorporated into pension reform programe in order to deepen the market. As these enterprises are privatized, there follows an increase in the available financial instruments to absorb the capital accumulation that contributory pension funding engenders. This translates to the spontaneous development of the domestic capital market.

By the same token, it is to be expected that activities in the life subsector of the insurance industry will be sped up. Annuity contracts and life contracts constitute major investment outlets for pension accumulated funds. The insurance industry also invests in equity and bond subsector of the capital market, being one of the dominant institutional investors in the capital market. In mandatory Defined Contributory (DC) pension scheme, workers are often required to purchase term life and disability assurance in order to cover them and their dependants from accident or death prior to reaching retirement age (Stiglitz and Ug, 1996). 
These insured benefits do not depend on the contributions (premiums) paid by or on behalf of the covered workers, but are related to the salary earned prior to the occurrence of the incident that makes payment of benefits automatic. In Nigeria, for instance, pension reform Acts, 2004, section 9, subsection 3, provides that...employers shall maintain life insurance policy in favor of the employee for a minimum of three times the annual total emolument of the employee. They are, therefore, of a defined benefit nature and highlight the hybrid nature of pension arrangements involving elements of both DC and DB plans.

It was once observed that a dominant factor in the success story of the Asian Tigers was the financial system deepening created by the economies. Of note in the financial systems development process was the compulsory pension plans of Malaysia and Singapore (Stiglitz and Ug, 1996). Although mixed results were claimed, it was, however, observed that most East Asia's fully funded pension plans were more likely to increase the national savings (Stiglitz and Ug, 1996). Little empirical support of a negative effect of pension funds on private savings in Japan and aggregate savings in Singapore was found [Ibid]. In clear support of the financial systems developmental effect of pension systems reform, it was once observed that a clear proportional relationship between general economic development and the growth of insurance has been noticed (Farny, 1999).

Defined contribution (DC) pension plans have, thus, become popular in the global pension market also because recent increases in longevity have increased pressures on defined benefit (DB) pension plan providers (Yang and Huang, 2012). That people now live longer than were statistically envisaged means that pension funds have many more years to support retirees. Hence, the longevity gain and the 'graying' of the global population (ie., that a small working age population has to support more and more old people) have increased the popular demand for a reform of public sector pension funding modality, which hitherto had been on the basis of pay-as-you-go, especially in the OECD countries (Diamond, 1995). The Pension Reform Act, 2004 in Nigeria was simply an imitation of a global phenomenon. The reform was expected to impact positively on the financial system development of the country.

3.1. The contributory pension and the national savings. Guthmann (1952) has aptly remarked that the creation of private pension funds means that the investment markets are to receive an inflow of funds that is made regular by long term contractual arrangement. Pension, being a contract, means that the inflow remains regular and predictable, unless there is a fundamental shift in the contract environment. By its very nature, pension funding is held to create huge savings because of the separation between accumulation phase and decumulation (liquidation) phase when pension payment falls due. This inter-temporal difference creates a fund supply of a long term nature. This is why pension funds, as institutional investors, wield unparalleled influence in the financial market as a supplier of funds in both the stock exchange and mortgage markets. Loayza et al. (2000) have predicted that most countries of Latin American origin and Europe now advocate for a shift from pay-as-you-go funding system to fully funded schemes on account of its favorable impact on saving. They, however, cautioned that the impact of funded pension on savings is not a given, but depends on how the transition deficit is financed and on the reform's efficiency gains. They put forward the view that pension reform should have little short run impact on private saving if it is financed by issuing public debt, since this entails converting an implicit government liability into an explicit one. On the other hand, should the transition be financed by reducing non-pension public deficit (i.e., lower net benefits to current retirees, impose higher taxes on current workers, or cut back on current government expenditures), saving levels of current generations will fall, while those of future generations will rise, although their saving rates may not necessarily change.

On a long term account, pension reform is predicted to have additional effects on savings through mandatory saving requirements (Loayza et al., 2000). Singapore's Central Provident Fund that imposed minimum retirement contributions of $25 \%$ of salary becomes a classic case in this regard. These requirements was said to be capable of increasing the saving of low-income borrowingconstrained earners well above what they would have saved otherwise. The welfare implication of such is, however, open to question.

Edwards (1998) argues that one of the phenomenal impacts of pension reform has remained its ability to raise the national saving rate. He stressed that Chile provides a test case in which it was claimed that savings climbed from $10 \%$ in 1985 to about $29 \%$ in 1996. He, however, pointed out that it may be unclear whether Chilean reform has actually increased private savings directly. The matter on private saving was further investigated. Haindl (1996) in Edwards (1998) constructed an econometric model to estimate the effect of pension on private sector savings. And using time series analysis of determinants of saving that includes 
series of dummy variables, he concludes that the reform indeed contributed to private sector savings. Morande (1996) who used error correction model of saving for Chile, concludes that there is preliminary evidence that support the notion that reform of the pension sector encouraged private sector savings.

Over all, the impact of pension reform on savings is mixed. For instance, Anglo-American and Scandinavian countries have high levels of pension funding, but very low saving rates, while countries like Switzerland, Singapore and Malaysia have both high levels of funding and saving rates (Vittas, 1995).

3.2. Contributory pension and capital market development. As Diamond (1996) has argued, one advantage of reform of pension is its potential contribution to the development of capital markets. As is usually the case, the introduction of privatized pension system naturally creates an accumulation of funds. With funds accumulation, the need for fund management emerges. The financial market players, then, respond by introducing different financial products that cater for the needs of the consumers of financial services. Both the money market and capital market instruments/securities are developed. Products that may become the toasts of investors include fixed deposit instruments, stocks and shares, annuity contracts and life assurance policies. In process of time, the attendant proliferation of financial services translates into financial market development, especially the capital market subsector.

It is also claimed that investment is a technical job which requires high training, experience, ability and judgment supported by extensive and constant research (Howell, 1958). The deployment of such managerial skill should result in superior earnings above the mediocrity and only if the relevant options are chosen from the universe of best investment options. The capital market offers varieties of those options. Pension fund is a key driver of the development of the capital market, being a dominant institutional investor (Valde'sPrieto, 1995). In fact, Howell (1958) has since acknowledged its overwhelming influence, when he averred that pension funds have become a new financial giant in today's capital market. Balogun (2006) also extrapolated that Pension Reform Act (PRA) in Nigeria was to generate over N900b long term loanable fund annually. According to him, a good proportion of the fund will be available for trading at the capital market, notably, the Nigerian Stock Exchange.

In assessing the Chilean experiment, Ogwumike (2006) claimed that the capital market advanced remarkably in size, depth and liquidity. Furthermore, it was held that stock transactions grew faster than GDP; fixed income transactions and financial intermediation grew tremendously; stock market asset valuation grew greatly, while asset values attained an average growth rate of $56 \%$.

The aggregate impact of the contributory pension on capital market, as evidenced in Nigerian case, is the financial deepening of the market. Financial deepening is held to mean an increase in the supply of financial assets in the economy and, therefore, the sum of all the measures of financial assets gives the size of financial deepening (Ndebbie, 2000 in Asekunowo, 2010).

As OECD (2005) in Asekunowo (2010) observed, institutional investors, especially pension funds, mutual funds and insurance firms have enhanced their role as collectors of savings over the past few decades. It concludes by affirming that the trend would likely continue as retirement savings grow and the increased pension fund saving augments the size of the capital market. The large pool of the savings in the care of pension account must be channelled into portfolios offering reasonable returns so that the pension debt obligations can be met as and when due. For this to happen, a high degree of financial intermediation that brings together the deficit and surplus units at the Stock Exchange Market is given. Such a marriage of seekers and givers of long term funds naturally results in the financial deepening of the system. This in clear terms translates to capital market development.

\subsection{The contributory pension system and the} financial system development in Nigeria. Financial system deepening is held to mean an increase in the supply of financial assets in the economy and, therefore, the sum of all the measures of financial assets gives the size of financial deepening (Ndebbie, 2000 in Asekunowo, 2010). Evidence accumulated from both theoretical and empirical literature point to the power of contributory pension to deepen the financial system. In an empirical study carried out by Asekunowo (2010) on the financial system deepening of the contributory pension regime in Nigeria, the results showed that the total domestic savings (TDS) increased during the post-pension period; and that the TDS was not GDP-induced. Although, he added, some measures of financial deepening such as $\mathrm{DCP} / \mathrm{GDP}$ (domestic credit to the private sector as a share of the GDP), TBD/GDP (i.e., Total Bank Deposit divided by GDP), and CIM (contract intensive money) did not show any remarkable improvement during the period, it was, however, observed that the DCP/GDP + SMC/GDP (domestic 
credit to the private sector as a share of the GDP plus the stock market capitalization as a share of GDP) measure showed a significant improvement following the implementation of the 2004 Pension Reform Act (as amended in 2014). This, according to him, is a key indication that the Nigerian capital market achieved some degree of financial deepening that can be reasonably attributed to the contributory pension system in place. This lends support to the claim that as at July end 2010, the number of registered workers stood at 4.5 million Nigerians with a total contribution figure of N1.77 trillion with an investment spread that reflects this pattern: $18.89 \%$ invested in ordinary shares $(\mathrm{N} 333.7 \mathrm{~b}) ; 37.64 \%$ invested in government securities (N669.1b); 1.74\% invested in corporate debt securities (N30.9b); 28.67\% invested in money market instruments (N509.6b); 0.45\% invested in open/closed end funds (N7.9b) and $2.61 \%$ invested in other instruments $(\mathrm{N} 224.1 \mathrm{~m})$.

Onwuamaeze (2011) further claimed that pension assets constitute $15 \%$ of the Nigerian banking assets, while also observing that a total of N950b and $\mathrm{N} 358 \mathrm{~b}$ have been invested by pension funds in bonds and equities that represent about 30\% and $8 \%$ of the bond and stock markets capitalization, respectively.

\section{Conclusion}

The paper looked into the implementation of the Pension Reform Act, 2004 and its possible effect on the deepening of the financial system development in Nigeria. Given that its practical implementation would entail accumulation of a pool of investible funds, it was easy to see how investing the funds have impacted positively on the money and capital market sectors of the economy. New financial products were created to absorb the emerging funds. This led to the development of the capital market sector, including the life insurance subsector. It was also observed that its implementation has created an impressive scenario whereby now pension funds account for $30 \%$ and $8 \%$ bond and stock markets capitalization, respectively.

\section{References}

1. Ahmed, I. (n.d.). Pencom to Force Merge Among Operators, Daily Trust.

2. Alles, L. (2010). Design Consideration for Retirement Savings and Retirement Income Products, Pension: An International Journal.

3. Anaesoronye, M. (2010). Only a Fresh Bill will Safeguard over 70\% of Small Nigerian Workers, Business Day, 118 (9).

4. Balogun, A. (2006). Understanding the New Pension Reform Act (PRA) 2004, CBN Bullion, 30 (2), pp. 7-18.

5. Biuomoyo, O.K. (2009). The Nigerian Pension System: Reform and Expectations, Pension: An International Journal, (1), pp. 3-10.

6. Colonial Government (1946). The Superannuation Scheme for Native, The Laws of Nigeria.

7. Diamond, P. (1995). Government Provision and Regulation of Economic Support in Old Age, Annual World Bank Conference on Development Economics.

8. Diamond, P. (1996). Government Provision and Regulation of Economic Support in old Age, Annual World Bank Conference on Development Economics.

9. Edwards, S. (1998). The Chilean Pension Reform. A Pioneering Programme. In Feldstein M. Privatizing Social Security, A National Bureau of Economic Research Project Report.

10. Ellison, R. (2011). The Role of the State in Pensions, Pension: An International Journal, 2 (16), pp. 67-78.

11. Farny, D. (1999). The Development of European Private Sector Insurance over the last 25 years and Conclusions that can be Drawn for Business Management Theory of Insurance Companies, The Geneva Papers on Risk and Insurance, 2 (24), pp. 145-155.

12. Guthmann, H.G. (1952). Effect on the Economy of Channeling Saving through Pension Funds, The Journal of Finance, 7 (2), pp. 260-295.

13. Howell, P.I. (1958). Pension Funds and the Capital Market: A Re-Examination of Pension Fund Investment Policies, The Journal of Finance, 13 (2), pp. 260-273.

14. Lindsay, C. (2009). Public Sector Pension: Broken Promises. Available at: http:www.personneltody.com/articles. Accessed on $26^{\text {th }}$ Feb. 2009.

15. Loayza, N., Schmidt-Hebbel, K. and Serven, L. (2000). Saving in Developing Countries: An Overview, The World Bank Economic Review, 14 (3), pp. 393-414.

16. Morande, F. (1996). Savings in Chile: What Went Right? Working Paper no 322. Washington, D.C. : InterAmerican Development Bank, Office of the Chief Economist.

17. Odo, C.O. and Igbeka, V.C. (2011). Public Sector Pension Reform in Nigeria : Progress and Challenges, The Four Pillars, (48), pp. 1-5. Available at: www.genevaassociation.org.

18. Ogwumike, F.O. (2008). Prospects and Challenges of 2004 Pension Reform Scheme in Nigeria: Some Lessons from the Chilean Experience, Bullion, 33 (2), pp. 3-16.

19. Oloja, M. (2010). Pension Scam Revealed, The Guardian, 11610 (28), p. 3.

20. Oluoma, R.O. (1986). Pension Systems in Nigeria: Past and Present (An Undergraduate Research Project Submitted to the Dept of Insurance and Actuarial Science, ASUTECT). 
21. Onwuamaeze, D. (2011). The Travails of Pension Contributors, Newswatch, 54 (26), pp. 12-17.

22. Osekunowo, V.O. (2010). Funded Contributory Pension Scheme, Financial Deepening and Economic Growth: What Does the Evidence say, so far about the Nigerian Economy, CBN Bullion, 33 (4), pp. 35-46.

23. Quisser, M. (1999). Pension Reform: Lesson from Latin America, Policy Research Brie, (15).

24. Shah, H. (1997). Towards Better Regulation of Private Pension Funds. The World Bank Policy Research Working Papers 1791.

25. Stigliz, J.E. and Ug, M. (1996).Financial Markets, Public Policy and East Asian Miracle, The World Bank Research Observer, 2(11), pp. 249-276.

26. Uwajaren, W. (2004). The Looting of Pension. Tell, 30, pp. 18-23.

27. Valde's-Prieto, S. ( 1995 ). Comment on Government Provision and Regulation of Economic Support in Old Age. Annual World Bank Conference on Development Economic, World Bank.

28. Vittas, D. ( 1998 ). Regulatory Controversies of Private pension Funds, Policy Research Working Paper, (893).

29. World Bank (1994). Averting the Old Age Crisis, Policies to Protect the Old and Promote Growth. A World Bank Policy Research Report.

30. Yang, S.S. and Huang, H. (2012). The Impact of Longevity Risk on the Optimal Contribution Rate and Asset Allocation for Contribution Pension Plans, The Geneva Papers on Risk and Insurance, 34, pp. 660-671. 